\title{
Implicitation and Deletion in the Translation of Band of Brothers' Subtitle and Their Effect on the Translation Quality
}

\author{
Muhammad Fajar Aryana, M. R. Nababan, Djatmika \\ muh_faj_ar@yahoo.com,_Amantaradja@yahoo.com,djatmika@staff.uns.ac.id \\ Master Degree Program in Translation Studies, Universitas Sebelas Maret, Surakarta
}

\begin{abstract}
The space for the subtitle has been a limited space for translators to accommodate the whole message from source to target language. However, the combination between textual multimodality and the techniques of how to make it more implicit should bridge the gap between message of the target text and the viewers. The viewers can still catch the meaning of the utterance not only based on the text but also from the other modality such as gesture, audio and other audio-visual effect on the scene.This study aims to find out the effect of implicitation and deletion, used in translating subtitle, on translation quality. The translation quality assessment includes the level accuracy, acceptability and readability of the text. This study is also a pilot study for the master degree thesis exploring the translation techniques, in this case implicitation and deletion, which are commonly used in subtitle to make the source text more implicit in the target text. Based on the findings of the research, the translators tends to apply implicitation rather than deletion to make the text more implicit.
\end{abstract}

Keywords: implicitation, deletion, translation quality assessment

\section{Introduction}

In the process of translating the subtitle, there are several rules to which the translator has to relate and consider. Those rules have made the translator more limited and bound other than translating any other form of text like novel or book. As Karamitroglou (1998) had proposed earlier in his study about a set of rules or standard in subtitling, which covers position of the text; segmentation and the length of the text line; numbers of lines; number of characters per line;duration; etc., the need of simplification or making the subtitle more concised became more and more inevitable.

The other related studies connected to implicitation are mostly brought together with the concept of explicitation as the argument toward Klaudy's operational asymmetry
(2001) and Klaudy and Karoly's theory of explicitation and implicitiation (2005). They did not relate implicitation with the other translation techniques such as deletion and did not connect the discussion further with translation quality assessment.

Hjort-Pedersen dan Faber (2010) in their research used legal text translation from beginner translator and found that obligatory explicitation and implicitation as the most occurrences. Hjort-Pedersen dan Faber (2013) continued their research on explicitation and implicitation from three translated legal texts based on three parameters; influence in meaning transfer, authenticity and informative function of translation. Sorensen (2010) used five legal texts along with the translation and found that explicitation occurred five times more frequent than implicitation with comparison five texts out of 
six texts. Kruger (2013) conducted research on explicitation and implicitation in the context of scientific and technical translation with cognitive linguistics as the approach. Murtisari (2013) found the meaning shifts caused by explicitation and implicitation using relevance theory and scalar typology as the approach. She also found that using those approaches is more accommodative and more consistent on the classification. Hariry (2014) concluded that implicitness found in subtitle is more frequent than in dubbing version by comparing and analyzing five different movies. Mozetic (2014) identified background, consequence and solution of implicitation and explicitation which were the most frequent techniques used in literature translation in Slovenia. He also found that explicitation acts as a shield or cover for beginners to play more safely as translators and which differs them from experienced translator.

In this study, it will be presented the concept of implicitation and deletion in their application of translating subtitle and their effect toward the translation quality using pragmatics as the approach. The translation quality assessment itself covers the level of accuracy, readability and acceptability.

\section{Methods}

This study is a descriptive and qualitative study because the data are utterances or in other word is a document, multiple, collected based on the purpose of the study and cannot be separated from their context. It is an embedded case study where the writer analyses implicitation and deletion in the subtitle of Band of Brothers and its translation in Indonesian. It can also be categorized into ethnographic study since the writer has to take part in collecting data and information. The information collected in this study is about the translation quality assessment from reliable informants who have background knowledge in translation and are expert to this field. Pragmatics has been chosen as the approach to determine which utterances are experiencing implicitation and deletion, since utterances cannot be separated from context and context in conversation is related to pragmatics.
The main data source is Band of Brothers miniseries' subtitle, its translation in Indonesian version and information about translation quality assessment which are collected from the informant or rater. Meanwhile, the data in this study are classified into two, the first one is the primary, which are utterances containing implicitation and deletion in Band of Brothers' subtitle, their translation and translation quality assessment, and the second one is the secondary data which contains information from other studies or journals related to this study.

In collecting the data, criterion-based selection is used to determine the data criteria and informant. The techniques in data collection are document analysis, questionnaire and interview or focused group discussion. Document analysis is used to determine utterances in subtitle which are experiencing implicitation and deletion. Questionnaire and interview or focused group discussion are used to collect the data about translation quality assessment. Data analysis includes domain, taxonomy, componential and also theme analysis (Spradley, 1980).

\section{Result}

\section{Type of Implicitation}

In their previous study, Vinay and Darbelnet define implicitation as "A stylistic translation technique which consists of making what is explicit in the source language implicit in the target language, relying on the context or the situation for conveying the meaning" (1995:344). Then, according to Klaudy and Karoly (2005:15), "Implicitation occurs, for instance, when a SL unit with a specific meaning is replaced by a TL unit with a more general meaning; when translators combine the meanings of several SL words in one TL word; when meaningful lexical elements of the SL text are dropped in the TL text; when two or more sentences in the ST are conjoined into one sentence in the TT; or, when ST clauses are reduced to phrases in the TT, etc." From this definition, implicitation can be classified into several types.

The first type of implicitation can be defined as an occurrence of a SL unit with a 
specific meaning is replaced by a TL unit with a more general meaning.

\section{Data EPS01D14}

ST: No, it's all right. We're Tommies, We're being Boche.

TT: Tidak apa-apa. Kita teman. Tidak sakit Bosch.

Teman in this case has the same meaning with 'friend', while Tommies means 'British soldiers'. The translator decided to choose teman which has more general meaning.

\section{EPS04D106}

ST: But if I can't see the bugger, I can't bloody hell shoot him, can I?

TT: Jika aku tidak bisa melihatnya maka aku tidak bisa menembaknya kan?

On the first part of occurrence, it is an implicitation which convert the word with a more specific meaning 'bugger' into a more general one '-nya'. 'Bugger' is an offensive word to express that a person is a silly and annoying one, while in the Indonesian version it is only represented in the word '-nya' which has the same meaning with 'it' for undefined object and 'him' or 'her' if the speaker and the partner already set their common understanding or knowledge to the subject of conversation. On the second occurrence, there is another technique which dropped the swearing word in the source text. This technique is called 'reduction' and it affects the accuracy level in the translation quality assessment. If the utterance only consists of implicitation, then the accuracy level will stay on the highest score. Since there is reduction on the same utterance, then the level of accuracy will drop one to the lower level.

The second type of implicitation is when the meanings of several SL words are combined into one TL word.

\section{Data EPS01D30}

ST: Soon your son will be dropped from the sky to engage and defeat the enemy.

TT: Putramu akan segera melakukan penerjunan untuk berperang.

Berperang has the closest meaning 'to go to war', while 'engage and defeat the enemy' has the identical idea with 'going to war'. That is why the translator combined the two words into one.

\section{EPS11D229}

ST: And then I saw an arm stuck out of the tent and one of the potato masher grenades, you know with stick come out of there.

TT: Lalu aku melihat sebuah tangan keluar dari tenda itu dan salah satu granat yang mempunyai tongkat, keluar dari tenda itu.

'Potato masher grenades' which refer to a specific kind of grenade in military field and consists of three words then combined into just one word 'granat' or 'grenade'.

The third type of implicitation is when meaningful lexical elements of the SL text are dropped in the TL text.

\section{Data EPS01D12}

ST: You are hereby transferred out of my regiment.

TT: Kau dikeluarkan dari resimenku.

'Hereby' has the same meaning dengan ini in Indonesian. In this, case the translator dropped the word 'hereby'. Eventhough the word 'hereby' is dropped from the target text, the viewers can still understand that the speaker wants to expel his partner out from his unit. The word which is dropped is just the small part and not really affecting the whole utterance. It is neither affecting the meaning nor the main message of the utterance.

\section{EPS01D16}

ST: Sorry about your brother, Bill.

TT: Aku turut menyesal, Bill

In this data, it is not only one element but there are two meaningful lexical elements which are dropped. However, even if the viewers cannot see those elements on the subtitle, they can still get the main message of the text. The utterance on the target text still shows the offering of condolence from the partner to the speaker.

\section{EPS10D219}

ST: It's just if the war is still on in Pacific and I could do some good over there. 
TT: Tapi jika perang masih berkobar di Pasifik dan aku bisa membantu.

Implicitation occurs in this utterance by dropping 'over there' and there is another technique which changes the meaning of 'only' in the word 'just' with the word 'tapi' which offers the meaning 'but' in the target text. The second technique occurs in the beginning of the text is called 'discursive creation'. It decreases the level of accuracy of the text from the highest level into the second lower level.

The fourth type of implicitation is when two or more sentences in the ST are conjoined into one sentence in the TT.

\section{Data EPS01D02}

\section{ST: How far up? How far down?}

TT: Seberapa jauh?

Seberapa jauh has the meaning 'how far'. In this case, the translator sees that 'how far up' and 'how far down' can be simplified but can still convey the meaning of asking how far'.

The fifth type of implicitation is when ST clauses are reduced to phrases in the TT.

\section{Data EPS05D131}

ST: He is recovered but it's going to be a long haul

TT: Dia akan sembuh, tapi lama

Lama in Indonesian has the same meaning with 'long'.

\section{Deletion or Omission}

The deletion of a part or the whole part of the SL text and the message is not conveyed in other part of the TL text. In this technique the meaning of the text is lost as well as the text (Molina and Albir, 2002)

\section{Data EPS01D10}

ST: Tipper: No, sir, it's here. You're a full grid off.

TT: Tidak, Pak. Persimpangannya di sini.

As it can be seen from the data, the second utterance, 'You're a full grid off', is completely deleted along with the message which the source text meant to carry. Therefore, there is no process of meaning transfer in this data because the viewers cannot get a part of the text let alone the full version of the text.

\section{EPS05D132}

ST: I'm out of here. I'm going to Rheims

TT: Aku pergi ke Rheims

Without the presence of 'I'm out of here', the viewers will not be able to know that the speaker has the willingness to go out of the room and to find out that there is such utterance exists. Deletion has been a technique which occupies the lowest level of accuracy, acceptability and readability because the utterance or the text in the source language is completely erased without leaving any single or small part of the source text.

From all the data which has been found in this research, there are 25 occurences with first type of implicitation, 8 occurences with second type, 30 occurences with third type, 2 occurrences with fourth type and 1 occurrence with fifth type from overall data in Band of Brother's subtitle translation.

\section{Translation Quality Assesment}

The translation quality assessment (TQA) in this study, there are three aspects which have to be considered. These TQA parameters had been proposed by Nababan et al (2012:50) earlier which covers accuracy, acceptability and readability. Accuracy means the TT has equal meaning or message with the ST. A text can be said as the text with high acceptability if it has already conveyed the message (from the ST) in accordance with rules, norms and culture in the TT. Readability has something to do with the level of understanding and easy-to -read by the reader. 
Table 3.1

\begin{tabular}{|l|c|c|c|c|c|c|c|c|c|}
\hline \multirow{3}{*}{ Technique } & \multicolumn{1}{|c|}{ Translation Quality Assesment } \\
\cline { 2 - 11 } & \multicolumn{4}{|c|}{ Accuracy } & \multicolumn{3}{c|}{ Acceptability } & \multicolumn{2}{c|}{ Readability } \\
\cline { 2 - 11 } & A & LA & NA & A & LA & NA & HR & MR & LR \\
\hline Implicitation & $\mathbf{5 0}$ & $\mathbf{1 7}$ & 0 & $\mathbf{6 7}$ & 0 & 0 & $\mathbf{6 7}$ & 0 & 0 \\
\hline Deletion & 0 & 0 & $\mathbf{1 9}$ & 0 & 0 & $\mathbf{1 9}$ & 0 & 0 & $\mathbf{1 9}$ \\
\hline
\end{tabular}

\begin{tabular}{|l|l|}
\hline A-LA-NA & : Accurate-Less Accurate-Not Accurate \\
\hline A-LA-NA & : Acceptable-Less Acceptable-Not Acceptable \\
\hline HR-MR-LR & : High Readabilty-Medium Readability—Low Readability \\
\hline
\end{tabular}

From the result of analysis, there are 67 subtitle texts or utterances which have experienced implicitation in the process of translating. From those 67 overall occurences, there are 17 occurences which are categorized as less accurate processes of implicitation. Meanwhile, deletion makes 19 occurences in the subtitle translation process. All of them are categorized in the lowest level of accuracy, acceptability and readability.

\section{Discussion}

With the findings of implicitation mostly reach the perfect rate in TQA, it can be seen that the reason behind the high rate in TQA is because implicitation mostly doesn't affect the message from the ST, with only few parts of the text which are dropped, and the others are conjoined, combined or replaced with more general unit in the TT. Those parts of the text are also mostly not really essential part or have been the common knowledge in the movie.

The common knowledge which can assist the reader or audience in understanding the text with implicitation are the gesture of the actors or actresses, the scene, the sound or any other supportive feature in the movie. This phenomenon is what so called multimodality in translation whose theories have been widely explained by several scholars like Gottlieb, van Leeuwen, Kress and Diaz Cintas. Kress in Cope and Kalantzis [2000:183-184] explained that a text should not be considered as monomodality but rather a multimodality, as the text is connected to the senses of human being. The senses always gets in touch with the surroundings or the worls though the proses of hearing and seeing,that is why it is called multimodality or more than one processes at a time. The same circumstance happens in the level of subtitle in the movie, where more than modal or aspect are correlated and supported on to another. The text is supported by the audio and the gesture of the actors, the visual, to create a better understanding of the situation or scene in the movie.

The other 17 occurences of implicitation which reach "less accurate" rate consist of more than one technique in one data or utterance. For instance, one data can consist of two or maybe three techniques. The findings in this study show that those 17 occurences consist of reduction and discursive creation occur together with implicitation in one utterance. These techniques cause the rate in accuracy to drop.

Deletion, on the other hand, always fills in the lowest rate of TQA because the technique neither renders ST into TT nor delivers the message from ST to TT. The general reader of the subtitle without any proper background knowledge of ST will not be able to realize that there are some parts of ST which have been deleted by the translator.

Implicitation also becomes the preference for the translator in this movie to render the ST into the TT without 'hurting' the ST or making an ill-formed TT. The translator will still be able to convey the message to the reader by reducing, dropping, conjoining or generalizing the ST units into the TT. In other words, the tendency of using implicitation in this case is higher than using deletion.

Since this study mainly focuses on two techniques which have a tendency in making the ST more implicit in the TT, it will bring a 
better perspective if in the future study there will be a different combination of techniques, such as explicitation and implicititation with a further view of TQA. With that, there will be a clear view whether the translator of the subtitle have a tendency to make his or her text explicit or implicit and whether the explicitation has higher level in TQA than implicitation or vice versa.

\section{Conclusion}

Implicitation with the occurrence of meaningful lexical elements of the SL text are dropped in the TL text are the type with the most occurrence in overall data. This shows how the translator prefers to have implicitation rather than deletion to maintain the message from the ST with 67 occurrences to 19 occurences in the process of translating. Deletion is not favorable in the effort of making the ST implicit because the tendency to not translate the ST or convey the message but rather to delete the utterance completely. The only reason why implicitation has the low accuracy is when reduction and discursive creation are applied in the same utterance as implicitation, other than that implicitation will always have the highest rate for accuracy, acceptability and readability.

\section{References}

Arikunto, S. Prosedur Penelitian: Suatu Pendekatan Praktek. Jakarta: Bina Aksara, 1985.

Bell, T. Roger. Translation and Translating: Theory and Practice. New York: Longman, Inc., 1991.

Catford, J.C. A Linguistic Theory of Translation. London: Oxford University Press, 1974.

Cintaz, Jorge Diaz dan Anderman, Gunilla. Audiovisual Translation. New York: Palgrave Macmillan, 2009.
Cope, Bill dan Kalantzis, Mary. Multiliteracies: Literacy Learning and the Design of Social Futures. London: Routledge, 2000.

Hariry, Mehdi Bagheri. Implicitation in Dubbing and Subtitling. Fars: Islamic Azad University, 2014.

Hendrastuti, Retno. Kajian Terjemahan Metafora yang Menunjukkan Sikap Dalam Buku Motivasi The Secret. Tesis. Surakarta: UNS, 2012.

Hjort-Pedersen, Mette and Dorrit Faber. "Explicitation and Implicitation in Legal Translation - A Process Study of Trainee Translators" dalam Meta: Translators' Journal, vol. 55,hal: 237-250. 2010.

Hjort-Pedersen, Mette dan Faber, Dorrit. Expectancy and Professional Norms in Legal Translation: A Study of Explicitation and Implicitation Preferences dalam Fachsprache 1-2, 2013.

Karamitroglou, Fotios. A Proposed Set of Subtitiling Standards in Europe. Manchester: University of Manchester Institute of Science and Technology, 1998.

Katz, J. J. Propositional Structure and Illocutionary Force: A Study of The Contribution of Sentence Meaning to Speech Acts. New York: T. Y. Crowell, 1977.

Klaudy, Kinga and Karoly, Krisztina. Implicitation in Translation: Empirical Evidence for Operational Asymmetry in Translation dalam Across Languages and Cultures 6 (1), pp. 13-28, 2005.

Kress, G. and Van Leeuwen, T.. Reading images: The grammar of the visual design. London: Routledge, 1996

Krüger, Ralph. A Cognitive Linguistic Perspective on Explicitation and Implicitation in Scientific and Technical Translation dalam trans-kom 6 [2] hal:285-314, 2013.

Krüger, Ralph. Exploring the Interface between Scientific and Technical Translation and Cognitive Linguistics: The Case of 
Explicitation and Implicitation. Salford: University of Salford, 2014.

Larson, M.L. Meaning-based Translation: A Guide to Cross-language Equivalence. Lanham: University Press of America, Inc., 1984.

Leech, Geoffrey N. Principles 1984. of Pragmatics. New York: Longman, 1983.

Lincoln, Y.S. and Guba, E.G. Naturalistic Inquiry. Beverly Hills: Sage Publication, 1985.

Mey, Jacob L. Pragmatics: An Introduction, Second Edition. Oxford: Blackwell Publishing, 2001.

Millan, Carmen and Bartrina, Fransesca. The Routledge Handbook of Translation Studies. New York: Routledge, 2013.

Moleong, L.J. Metodologi Penelitian Kualitatif (Edisi Revisi). Bandung: PT. Remaja Rosdakarya, 2006.

Molina, Lucia dan Albir, Amparo Hurtado. Translation Technique Revisited: A Dynamic and Functionalist Approach dalam Meta XLVII 4: page 498-512, 2002.

Mozetic, Uros. Explicitation and Implicitation as Translation Universals and Their Occurrences in the Slovene Translations of Anglo-American Literary Texts dalam Elope.11.2.101-114, 2014.

Murtisari, Titik Elisabet. Relevance-Based Framework for Explicitation/Implicitation: A New Alternative dalam trans-kom 6 [2] hal:315-344, 2013.

Nababan, M.R. Teori Menerjemah Bahasa Inggris. Yogyakarta: Pustaka Pelajar, 2008.

Nababan, M.R. Pengembangan Model Penelitian Kualitas Terjemahan. Surakarta: Universitas Sebelas Maret, 2012.
Nida, E.A. dan Taber, C.R.. The Theory and Practice of Translation. Leiden: E.J. Brill, 1982.

Noss, Richard B. (ed.). Ten Papers on Translation. Singapore: SEAMEO Regiona; Language Centre, 1982.

Sørensen, Katrine Ravnkilde. Explicitation and Implicitation in Legal Translation: $A$ Qualitative Study of the Use of the Two Translation Strategies in the Translation of Legal Texts. Copenhagen: Copenhagen Business School, 2010.

Spradley, J.P. Participant Observation. New York: Holt, Rinehart and Winston, 1980.

Sutopo, H.B. Metodologi Penelitian Kualitatif: Dasar Teori dan Terapannya dalam Penelitian. Surakarta: Universitas Sebelas Maret, 2006.

Venuti, Lawrence. The Translation Studies Reader. London: Routledge, 2000.

Vinay, J. P. and Darbelnet, J. Comparative Stylistics of French and English. A Methodology for Translation. Amsterdam: John Benjamins. Translated by J. C. Sager and M. J. Hamel, 1995.

Wilss, Wolfram. Übersetzungswissenschaft. Probleme und Methoden, Stuttgart: E. Klett, translated (1982) as The Science of Translation. Problems and Methods, Tubingen: Gunter Narr, 1977.

Yin, R. K. Case Study Research, Design and Methods, 3rd Edition. Newbury Park: Sage Publications, 2003.

Yule, George. 1996. Pragmatics. Oxford: Oxford University Press 